

\title{
Vertical Readings in Dante's Comedy
}

\author{
Volume 2
}

edited by

George Corbett and Heather Webb 


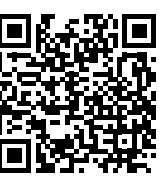

http://www.openbookpublishers.com

(C) 2016 George Corbett and Heather Webb. Copyright of individual chapters is maintained by the chapter's author.

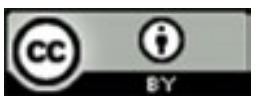

This work is licensed under a Creative Commons Attribution 4.0 International license (CC BY 4.0). This license allows you to share, copy, distribute and transmit the work; to adapt the work and to make commercial use of the work providing attribution is made to the authors (but not in any way that suggests that they endorse you or your use of the work). Attribution should include the following information:

George Corbett and Heather Webb (eds.), Vertical Readings in Dante's 'Comedy': Volume 2. Cambridge, UK: Open Book Publishers, 2016. http://dx.doi.org/10.11647/OBP.0100

In order to access detailed and updated information on the license, please visit https://www. openbookpublishers.com/product/499\#copyright

Further details about CC BY licenses are available at http://creativecommons.org/licenses/ by/4.0/

All external links were active on 01/12/2016 unless otherwise stated and have been archived via the Internet Archive Wayback Machine at https://archive.org/web

Every effort has been made to identify and contact copyright holders and any omission or error will be corrected if notification is made to the publisher.

Digital material and resources associated with this volume are available at https://www. openbookpublishers.com/product/499\#resources

ISBN Paperback: 978-1-78374-253-0

ISBN Hardback: 978-1-78374-254-7

ISBN Digital (PDF): 978-1-78374-255-4

ISBN Digital ebook (epub): 978-1-78374-256-1

ISBN Digital ebook (mobi): 978-1-78374-257-8

DOI: $10.11647 / \mathrm{OBP} .0100$

Cover image: The mosaic ceiling of the Florence Baptistery, also known as the Baptistery of Saint John (13th-15th century). Photo by Matthias Kabel, https://commons.wikimedia.org/ wiki/File:Florence_baptistery_ceiling_mosaic_7247px.jpg, CC BY-SA 3.0 Unported.

All paper used by Open Book Publishers is SFI (Sustainable Forestry Initiative), and PEFC (Programme for the endorsement of Forest Certification Schemes) Certified.

Printed in the United Kingdom, United States and Australia by Lightning Source for Open Book Publishers (Cambridge, UK). 


\section{Contents}

Acknowledgements vii

Editions Followed and Abbreviations $\quad$ ix

Notes on the Contributors xi

Introduction 1

George Corbett and Heather Webb

12. Centaurs, Spiders and Saints 13

Christian Moevs

13. 'Would you Adam and Eve it?'

Robert Wilson

14. The Patterning of History: Poetry, Politics and Adamic

Renewal

Catherine M. Keen

15. Dante's Fatherlands

Simone Marchesi

16. Politics of Desire

Manuele Gragnolati

17. Seductive Lies, Unpalatable Truths, Alter Egos

Tristan Kay

18. Women, War and Wisdom

Anne C. Leone

19. Inside Out 
20. Prediction, Prophecy and Predestination: Eternalising Poetry in the Commedia

Claudia Rossignoli

21. God's Beloved: From Pitch, Through Script, to Writ Corinna Salvadori Lonergan

22. Truth, Autobiography and the Poetry of Salvation Giuseppe Ledda

Bibliography

Index of Names 


\section{Prediction, Prophecy and Predestination: Eternalising Poetry in the Commedia}

\section{Claudia Rossignoli}

When we consider cantos in the Comedy that have strong 'vertical' links across the three cantiche, the Twenties are certainly not among the ones that immediately spring to mind. Although often individuated by Dante scholars as remarkable, these three cantos appear to have very little in common from a structural, narrative or thematic point of view. Inferno $\mathrm{xx}$ depicts the harrowing spectacle of the fourth bolgia, where the seers and diviners are fittingly punished for their deceptive claims and their bold aspiration to appropriate what is rightfully and exclusively divine, the ability to know the future. The description of this bolgia and of its uncanny atmosphere, of the debased figures that inhabit it and of their monstrous deformity, of their unique, defeated (and eerily silent) desperation, is markedly selfcontained. Inferno $\mathrm{xx}$ is interspersed, nonetheless, with an exceptional metatextual discourse and is characterised by stylistic hybridisation and a particular linguistic idiosyncrasy. Notably, this is one of the cantos with the highest number of hapax legomena, including the momentous 'tragedia' at 1 . 113 (to which we will return), and the infamous 'introcque' (1. 130), which confronts the reader in the canto's closing verse in a unique rhyme with the

1 I am especially grateful to the editors not only for their invitation to take part in the vertical experiment, but especially for their unfaltering support and learned advice during the completion of this chapter. 
other hapax 'nocque' (1. 128). ${ }^{2}$ Purgatorio $\mathrm{xx}$, on the other hand, opens with a very violent invective against the 'antica lupa' [ancient she-wolf] (1. 10) that anchors it strongly to the encounter with Adrian V in Purgatorio xix, and prepares the way for Hugh Capet's vehement tirade that occupies most of the canto (11. 40-123). This has just concluded when a dramatic sudden earthquake mysteriously shakes the mountain of Purgatory bringing the canto to its end with a powerful and suspensive coup de theatre (1l. 124-51).

When we move to Paradiso $\mathrm{xx}$, we find ourselves immersed in the exalting and enfolding light of the Heaven of Jupiter, where the just souls present themselves to Dante in the mesmerising and highly symbolic shape of an eagle. Having addressed the pilgrim's doubt about the mystery of divine justice in Paradiso xix, the eagle encourages him in the following canto to focus on its eye, where divine justice manifests itself more clearly in the souls of David, the Roman Emperor Trajan, King Hezekiah, the Emperor Constantine, William II of Altavilla, and the Trojan Ripheus (Par., xx. 31-73). The 'immagine divina' [divine image] then administers to the pilgrim a 'soave medicina' [sweet medicine], clarifying in mystical accents the salvation of the two 'gentili' [pagans] and declaring the inscrutability of predestination whilst warning all 'mortali' [mortals] to distrust their fallible judgement (11. 88-148). ${ }^{3}$

2 See also DVE, I.13.2, where 'introcque' is used to exemplify 'muncipalia vulgaria Tuscanorum'.

3 This is clearly a very brief summary of three typically rich cantos. It is not possible in this context to examine in detail all the significant elements that individually characterise them. I will only focus on the features and themes that allow us to construct a clearly 'vertical' discourse. For an analysis of each canto individually, and of some of the issues raised, see the following editions of the Comedy: The Divine Comedy, trans. and comm. by Charles Singleton (Princeton, NJ: Princeton University Press, 1970-1976), La Divina Commedia, ed. by Umberto Bosco and Giovanni Reggio, 3 vols (Florence: Le Monnier, 1988); The Divine Comedy of Dante Alighieri, ed., trans. and notes by Robert M. Durling and Ronald L. Martinez, 3 vols (Oxford: Oxford University Press, 1996-2011); and Commedia, ed. by Anna Maria Chiavacci Leonardi, 3 vols (Milan: Mondadori, 1991-97). In the extensive bibliography available for Inferno xx, I relied especially on Giorgio Barberi Squarotti, 'Interpretazione della struttura del canto XX dell'Inferno', Ateneo Veneto (1965), 273-302; Ernesto Parodi, 'Il canto xx dell'Inferno', in Letture dantesche. Inferno, ed. by Giovanni Getto (Florence: Sansoni, 1964), pp. 379-91; M. Barchiesi, 'Catarsi classica e medicina dantesca. Dal canto XX dell'Inferno', Letture Classensi 4 (1973), 9-124; Robert Hollander, Studies in Dante (Ravenna: Longo, 1980), pp. 131-218; Teodolinda Barolini, 'Canto XX: True and False See-ers', in Lectura Dantis: Inferno, ed. by Allen Mandelbaum, Anthony Oldcorn and Charles Ross (Berkley, CA: University of California Press, 1998), pp. 275-86; Georges Güntert, 'Canto XX', Lectura Dantis Turicensis I, ed. by Georges Güntert and Michelangelo Picone (Florence: Cesati, 2000), pp. 277-89; Piero Boitani, 'Inferno Canto XX', Lectura Dantis Andreapolitana, University of St Andrews, 6 May 2011, http://lecturadantisandreapolitana.wp.st-andrews.ac.uk/video/inferno-canto-xx; 
At first sight, then, the Twenties seem to pursue very different concerns. The experiment of 'vertical' reading may open up and reveal, nevertheless, a significant web of connections between these three cantos that operates on semantic, symbolic and allegorical levels. These connections arguably serve to highlight a persistent, and vertically coherent, discourse about the powers of the human mind and its blatant limitations, about rightful objectives and misplaced ambitions, and about Dante's own attempt to eternalise his poetry through a radical rethinking of classical literature and a provocative appropriation of Scripture. Whilst it might be far-fetched to force the hypothesis of a conscious and planned alignment on Dante's part, it is clear that the elements that will be discussed below form part of a broader and compelling bridging strategy operating 'at structurallymarked moments ${ }^{\prime 4}$ across the poem that hinges on key aspects of Dante's conception of being and of scriptural poetics. ${ }^{5}$

The first striking element that recurs in the three cantos is a consistent and emphatic reference to the semantic field of eyes and sight, which is

Sonia Gentili, 'Canto XX. Deformità morale e rottura dei vincoli sociali: gli indovini', in Lecutra Dantis Romana. I. Inferno. 2. Cantos XVIII-XXIII, ed. by Enrico Malato and Andrea Mazzucchi (Rome: Salerno, 2013), pp. 646-81. For Purgatorio xx, see at least Pio Rajna, 'Ugo Ciappetta nella Divina Commedia', Studi Danteschi 37 (1960), 5-20; R. Scrivano, 'L'orazione politica di Ugo Capeto: morale, politica e retorica in Dante', L'Alighieri 12 (1971), 13-34; M. Marti, 'Il pianto di Ugo Capeto e il natalizio "Gloria" nell'unità del XX del Purgatorio', in GSLI 162 (1985), 321-43; A. Stäuble, 'Canto XX', in Lectura Dantis Turicensis. Purgatorio, ed. by Georges Güntert and Michelangelo Picone (Florence: Cesati, 2001), pp. 307-14; M. Grimaldi, 'Canto XX. La regalità dei nuovi capetingi', in Lectura Dantis Romana. II. Purgatorio. 2. Canti XVIII-XXXIII, ed. by Enrico Malato and Andrea Mazzucchi (Rome: Salerno, 2014), pp. 583-620; Robert Bartlett, 'Purgatorio Canto XX', Lectura Dantis Andreapolitana, University of St Andrews, 15 November 2013, http://lectura dantisandreapolitana.wp.st-andrews.ac.uk/video/purgatorio-canto-xx. For Paradiso xx, I found especially helpful John A. Scott, 'Dante, Boezio e l'enigma di Rifeo (Par. XX)', Studi Danteschi 61 (1989), 187-92; Andrea Battistini, "'Rifeo troiano" e la riscrittura dantesca della storia', Lettere Italiane 42.1 (1990), 26-50; Michelangelo Picone, 'Canto XX', in Lectura Dantis Turicensis. Paradiso, ed. by Georges Güntert and Michelangelo Picone (Florence: Cesati, 2002), pp. 307-24; L. Serianni, 'Lettura del canto XX del Paradiso', Filologia e Critica 28.1 (2003), 3-22; Marco Ariani, Lux inaccessibilis. Metafore e teologia della luce nel 'Paradiso' di Dante (Rome: Aracne, 2010), pp. 245-67; Claudia Villa, 'I cieli di Marte e di Giove', in Esperimenti danteschi. Paradiso, ed. by Tommaso Montorfano (Genoa: Marietti, 2010), pp. 185-99; Erminia Ardissino, "“Ciascuna cosa qual ell'è diventa" (Pd. XX, 78). Metamorfosi e vita beata', Lettere Italiane 63 (2011), 208-23; and Nicola Fosca, 'Il canto XX del Paradiso. Giustizia e predestinazione', Studi Danteschi 79 (2014), 209-66.

4 See Simon Gilson, 'Medieval Magic Lore and Dante's Commedia: Divination and Demonic Agency', Dante Studies 119 (2001), 27-66 (p. 54).

5 For a seminal illustration of Dante's 'scripturality', see the classic Peter S. Hawkins, Dante's Testaments: Essays in Scriptural Imagination (Stanford, CA: Stanford University Press, 1999), esp. pp. 19-95. 
continuously characterised by significant allegorical undertones. In Inferno $\mathrm{xx}$, a canto dealing with those who wanted to see too far ahead ('veder troppo davante', 1. 38) and whose meticulously calculated punishment consists in a violent distortion of their physical capacity to see, such insistence is indeed to be expected. However, in no other bolgia as in this one do we see such a striking construction of what the pilgrim is experiencing in terms of a spectacle that he is to absorb through his eyes, a spectacle in fact that will be literally revealed to him, as announced in the concluding verse of the previous canto: 'Indi un altro vallon mi fu scoperto' [from there another valley was revealed to me] (Inf., xix. 133). The sense of visual expectation created by this explicit is then heightened by the almost immediate repetition of 'scoperto' at the beginning of Inferno xx, and reinforced by the pilgrim's disposition to 'riguardar' [gaze] leading, in turn, to a progressive disclosure of what the pilgrim sees, from the emphatic 'e vidi' [and I saw] of line 7 :

Io era già disposto tutto quanto a riguardar ne lo scoperto fondo, che si bagnava d'angoscioso pianto; e vidi gente per lo vallon tondo venir, tacendo e lagrimando, al passo che fanno le letane in questo mondo. (Inf., xx. 4-9)

[I was already bent over to gaze into the uncovered depth, which was bathed with anguished weeping; and I saw people coming along the curving valley, silent and shedding tears, at the pace taken by litanies in this world.]

The sinners, at least momentarily, appear to emanate a sense of tragic penitential gravity, expressed in their distinctive and absorbed silence, in their strangely composed demeanour, and in their delayed and impeded movement. The almost solemn pace of their proceeding seems to evoke that of earthly religious processions but its actual characteristics will soon reveal the inverted nature of this representation. In fact, as soon as the pilgrim literally looks closer ('Come '1 viso mi scese in lor più basso' [As my gaze went lower on them], 1. 10), his gaze becomes a powerful device to establish a sophisticated dynamic of correlation and reversal. Most obviously, the pilgrim's own sight contrasts with the sinners' aberrant blindness, caused by a uniquely matched contrapasso both in physical and allegorical terms. The compensating and reversing logic of the diviners' 
punishment, whose heads are unnaturally twisted backwards, is clear. In opposition to their mainly solitary and secluded existence, the diviners are now not just blinded and forced to be part of a large group but also obliged by the physical nature of their punishment to proceed at a synchronised, regimented pace; their silence contrasts with their garrulity in life while their penitential demeanour counteracts their previous arrogance. ${ }^{6}$ However, their degraded humanity is depicted specifically through the progressive visual scanning of their deformed bodies, hinging insistently on their deprivation of sight, in direct opposition to their mortal existence as well as to Dante personaggio's intense stare:

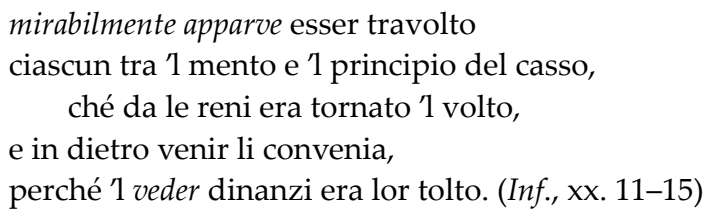

[each was marvellously twisted between the chin and the beginning of the chest, for the face was turned towards the kidneys, and they were forced to walk backwards, since seeing forward was taken from them.]

It is clear that sight and all its semantic cognates establish here a specular opposition between Dante-character, actively seeing and able to experience and communicate his truthful 'vision', 7 which has been sanctioned by divine grace, and the sinners he is observing, who are no longer able to see because of their direct challenge to the boundaries established by divine authority. ${ }^{8}$

In a clearly antiphrastic construction later on in the canto, the seers' fraudulent and misguided desire to appropriate a uniquely divine prerogative are also expressed in terms of their own seeing ('veder', 1 . 38; 'guardare', 1. 50), and again their sinful practices and false claims are directly contrasted to their current dehumanised status. This apparently forceful and clear-cut opposition is immediately complicated, nonetheless,

6 This seems unusual as in Dante's Hell the sinners are more normally immortalised in the specific sinful act or attitude that typifies their sin and determined their damnation.

7 This is specifically defined as such in Par., xvii. 128. On this contrast, see also Gentili, 'Canto XX', p. 647.

8 On the particular nature of the diviners' sin, see, for example, Achille Tartaro, 'Canto XX', in Lectura Dantis Neapolitana. Inferno, ed. by Pompeo Giannantonio (Naples: Loffredo, 1986), pp. 341-64; and Gilson, pp. 35-37. 
by the pilgrim's affliction and tears at the sight of the cruelly unnatural course of the sinners' tears down their bodies, creating a direct and disturbing specularity with the seers' 'angoscioso pianto' ${ }^{9}$ The problematic character of this connection is singled out not just in Virgil's harsh and sudden outburst in response to this emotive crisis, but more significantly in Dante's direct appeal to the reader, an unequivocal signal of a textual issue worthy of careful consideration: ${ }^{10}$

Se Dio ti lasci, lettor, prender frutto

di tua lezione, or pensa per te stesso

com'io potea tener lo viso asciutto,

quando la nostra imagine di presso

vidi sì torta, che ' 1 pianto de li occhi

le natiche bagnava per lo fesso.

Certo io piangea, poggiato a un de' rocchi del duro scoglio, [...] (Inf., xx. 19-26)

[So may God permit you, reader, to take profit from your reading, now think for yourself how I could keep dry eyes, when from close by I saw our image so twisted that tears of their eyes were bathing their buttocks down the cleft. Surely I wept, leaning on one of the rocks of the hard ridge.]

Commentators have responded to the challenge, advancing numerous competing interpretations of the pilgrim's sorrow at this point. ${ }^{11}$ However, the specific extradiegetic dimension in which this crisis unfolds arguably points at a broader discourse that, like many other elements in the canto, extends beyond the boundaries of this canto or of this bolgia, and that,

9 The pilgrim's tears often signal his struggle to understand divine justice, as already in Inf., iii. 24 and as late as Purgatorio, xxx. 54. But I am convinced that they could indicate also a significant symptom of self-questioning, as in his epistle XI where he compares himself to Uzzah. See Robert Hollander, 'Dante as Uzzah? (Purg. X 57 and Ep. XI 9-12)', in Sotto il segno di Dante. Scritti in onore di Francesco Mazzoni, ed. by Leonella Coglievina, Domenico De Robertis (Florence: Le Lettere, 1998), pp. 143-51. At the same time, Statius's representation of the tearful Melampus and Amphiaraus at their fore vision is of crucial importance in a book that wonders 'unde iste per orbem / primus uenturi miseris animantibus aeger / creuit amor?', and is filled with tears since the return of Maeon, who 'signa dabat magnae longe manifesta ruinae / plactumque et gemitu', in Thebaid, III, 549, 551-52, and 43-44 respectively.

10 On the crucial metatextual function of Dante's appeals to the reader, see at least the classic Erich Auerbach, 'Dante's Addresses to the Reader', Romance Philology 7 (1954), 268-78; Leo Spitzer, Romanische Literaturstudien (1936-1956) (Tubingen: Niemeyer, 1959), pp. 574-95; and Vittorio Russo, 'Appello al lettore', in ED, I, pp. 324-26.

11 After the studies of Baldelli, Gorni, Cornish and more recently Gilson, it is no longer possible to dismiss Dante's interest in divination and other magic artes as 'laughable'. 
indeed, a 'vertical' perspective may help us to demonstrate more clearly. His tears, just like his gaze, are intended to encourage the reader to compare the difference, not immediately apparent but nonetheless fundamental, between the divination punished in this 'vallone' (Inf., xxxi. 7) and what Dante is doing 'in libro isto', as the commentator Benvenuto da Imola lucidly recognised. ${ }^{12}$ In fact, there is no real 'solidarietà' [solidarity] ${ }^{13}$ with the sinners themselves, as the pilgrim's tears register his dismay at their abuse of human intelligence and, consequently, the debasement of their human form in Hell.

In this sense, the pilgrim's reaction may echo the similarly emotional tears shed by Paul in the apocryphal Visio Pauli at the sight of a specific group of sinners, described by the angel in some versions of the text as those 'who sullied the marital bed, and denied their own children, [...] and did divinations and predictions' ${ }^{14}$ And, as in the Visio Pauli, Dante's guide is also quick to intervene and disperse any association created by this shared 'pianto' with an uncompromising reproach that brusquely ends this pathos-filled parenthesis. ${ }^{15}$ After apostrophising Dante as 'sciocco' for appearing to have compassion for the suffering of those rightly punished by divine justice, ${ }^{16}$ Virgil forcefully urges him to look at the inhabitants

12 With his characteristic perspicuity, Benvenuto connects the pilgrim's sorrow for the seers' punishment to the Comedy's ambitious prophetic aspirations. See Comentum, II, 67; 69.

13 See Barchiesi, pp. 54-56.

14 In L. Jiroušková, Die Visio Pauli. Wege und Wandlungen Einer Orientalishen Apokryphe im Lateinischen Mittelalter (Leiden: Brill, 2006), p. 203: 'que maculaverunt torum viri sui et negaverunt filios suos [...] et augurias et divinaciones fecerunt'. This is generally the text in manuscripts of Redaction I, like the Ms 28 of the Cathedral Library in Barcelona. All versions, however, include the scene of Paul crying and, although the angel's subsequent question is not always the same, the response of Paul's guide remains essentially unchanged: 'Et dixit angelus ad Paulum: Quid ploras?'.

15 The interpretation of Virgil's reproach is still a matter of significant scholarly contention. The Ottimo appears to summarize well, in my view, the essence of the moral problem highlighted by Virgil's attitude: 'Virgilio il riprende di questo piangere, a dimostrare che gli uomini non deono aver compassione a coloro che per divino giudicio patiscono de' loro peccati pena. Iob dice che nulla è peggiore di quello uomo, che ha pietade di cotali gente: avere compassione è patire pena in parte con lui, che ha peccato; participare con li rei, è parte di reitade'. See L'Ottimo commento della Divina Commedia, ed. by Alessandro Torri, 3 vols (Bologna: Forni, 1995), I, pp. 363-64.

16 Virgil's rhetorical question 'Ancor se' tu de li altri sciocchi?' at 1.27 is a direct calque of Matt. 15:16: 'Adhuc et vos sine intellectu estis?' [Are you also yet without understanding?], as noted by Tommaseo (see Niccolò Tommaseo, gloss to Inf., xx. 25-27, in Dartmouth Dante Project, https://dante.dartmouth.edu). From a 'vertical' perspective, it is also interesting to note the connection of the hapax 'sciocchi' to the rare 'stolti' [fools] of Par., xviii. 102, who 'sogliono agurarsi' [often take auguries] from the sparks that fly up from smouldering logs, as this contributes to the description of the movement of 'lights' that will form the eagle protagonist of Paradiso xx. 
of the bolgia with the imperatives 'vedi' [see] (repeated no less than seven times) and 'mira' [gaze].

In addition to such formulaic reiteration, the importance of sight is accentuated by clear visual signposting for each of the characters listed in the canto, both in the initial group of more clearly defined figures (Amphiaraus, Tiresias, Arruns and Manto) and in the second, less characterised group presented after a long digression on the foundation of Mantua, at lines 106-23 (Eurypylus, Michael Scot, Guido Bonatti, Asdente and the numerous 'wretched women who left their needles, spindles an distaffs, and became soothsayers'). ${ }^{17}$ As some critics have suggested, Virgil's emphasis on seeing and his repeated use of 'vedere' throughout his speech mimics the sinners' own divinatory language, cruelly mocking both their forced blindness and their current silence. This is particularly clear in the case of the first seer mentioned, Amphiaraus. ${ }^{18}$ His very public demise 'a li occhi d'i Teban' [before the eyes of the Thebans] (1. 32) not only reinforces the visual dimension of Virgil's discourse, adding to the pilgrim's gaze upon the sinner that of the scornful Theban crowds; ${ }^{19}$ it also rearranges the narrative elements of the classical sources to further diminish the Theban augur and highlight the severity of his error in openly scriptural terms, as in the powerful hyperbaton of 1.32 's'aperse [...] la terra' [the earth opened], a clear echo of Numbers 16.30 but also of 'aperta est terra' [the earth opened] (Psalm 105.17). ${ }^{20}$

The insistence on 'vedere' as well as on the 'occhi' in Dante's description of the diviners has, then, a specific scriptural quality and meaning, just as with the reproach at 11. 27-30. His imperative request at line 31, 'Drizza la testa, drizza e vedi' [Raise your head, raise it and see], literally translates the

17 Especially through the imperative 'vedi', repeated three times in two tercets at 11. 118-23.

18 On Amphiaraus, see at least the entry by G. Padoan in ED, I (1996), p. 265.

19 Many critics have highlighted how the popularising and violent language used in this canto to describe the diviners stands in powerful and direct opposition not only to the literary loftiness of Virgil's 'alta tragedìa' mentioned at 1l. 113-14, but also to the classical tradition from which the sinners here mentioned originate. The degrading punishment reserved for the diviners and the crude and mocking language with which it is exposed certainly operate also at an intertextual level, reflecting negatively on the classical sources that transmit the stories of these characters, degrading them and divesting them of any mythical quality. See, for instance, Tartaro, who indicates the canto's 'anti-literary' objective (p. 342).

20 Scholars have noted the connection of this representation with existing medieval contaminations between Statius's tale and the biblical one in Numbers. Interesting, in this sense, is Barchiesi's connection of Dante's representation of Amphiaraus to the Roman de Thèbe and its explicit reference to the demise of Dathan and Abiram in Numbers 16 (Barchiesi, pp. 92-98). 
'leva oculos tuos et vide' of Genesis (13.14 and 31.12) and the 'leva oculos tuos in directum et vide' of Jeremiah 3.2. ${ }^{21}$ In these particular cases, as more generally in Scripture, references to the ability to see signify the salvific power of revelation. ${ }^{22}$ So Virgil's literal insistence on gaining a full 'vision' of this scene denotes also the necessity for the pilgrim to acquire the spiritual truth of this manifestation of divine justice in order to progress towards the ultimate objective of his journey and, more importantly, to retell what he has seen, as the commentator Benvenuto da Imola lucidly points out. ${ }^{23}$ In fact, the entire representation revolves on the contraposition of these two different forms of 'vedere': on the one hand the diviners' fallacious and fraudulent desire to see, rooted in their arrogance and misplaced confidence in the human intellect, mortified through Virgil's aggressive words and tone; on the other, Dante's understanding and acceptance of the absolute truth and intellectual necessity of this (as of any other infernal) punishment as part of his authentic and salvific vision, accepted with a clear awareness of its purpose and humble recognition of its rightful limits (as it will become apparent in the eagle's 'soave medicina' that clears up the pilgrim's 'corta vista', in Par., xx. 130-41). ${ }^{24}$ Dante (through Virgil's voice)

21 Equivalent expressions recur also in the apocrypha, as in Baruch 2.17: 'Aperi oculos tuos et vide'. Neither these or the biblical antecedents of 1.32 are indicated in Carolynn LundMead and Amilcare Iannucci, Dante and the Vulgate Bible (Rome: Bulzoni, 2012), p. 104.

22 See, for example, 'Illumina oculos meos, ne umquam obdormiam in morte' [Enlighten my eyes that I never sleep in death] (Psalm 12.4) and 'audi populus stulte qui non habes cor qui habentes oculos non videtis et aures et non auditis' [Hear, $\mathrm{O}$ foolish people, and without understanding: who have eyes, and see not: and ears, and hear not] (Jeremiah 5.21). But also notably as in the gospels, as in 'Et aperti sunt oculi eorum, et cognoverunt eum' (Luke 24.31) or 'Vestri autem beati oculi quia vident, et aures vestræ quia audiunt (Matthew 13.16). See also Mark Brummitt, 'The Sublime Art of Prophetic Seeing: Aesthetics and the Word in the Book of Jeremiah', in Beauty and the Bible: Toward a Hermeneutics of Biblical Aesthetics, ed. by Richard J. Bautch and Jean-François Racine (Atlanta, GA: Society of Biblical Literature, 2013), pp. 23-30, and Francis Landy, 'I and Eye in Isaiah, or Gazing at the Invisible', Journal of Biblical Literature 131 (2012), 85-97.

23 See Comentum, II, 71: 'driccia la testa, idest, erige oculos mentis, et repetit istud verbum driccia, ut magis tangat eum, quasi dicat: non fleas amplius, fatue, non fleas, sed dimitte ipsos flere, et incede ad cognoscendum aliquos'. This is a typical characteristic of experiences of visions of the other world, as clearly documented in Giuseppe Ledda, 'Modelli biblici nella Commedia. Dante e San Paolo', in La Bibbia di Dante. Esperienza mistica, profezia e teologia biblica in Dante, ed. by Giuseppe Ledda (Ravenna: Centro Dantesco dei Frati Minori Conventuali, 2011), pp. 179-216.

24 The different objective is what essentially distinguishes Dante's operation from that of the diviners as their sin here is the self-centred and narcissistic desire to 'veder troppo davante' (1.38), the same desire to see too much as instigated by the serpent in Genesis 3.5: 'scit enim Deus quod in quocumque die comederitis ex eo aperientur oculi vestri, et eritis sicut dii, scientes bonum et malum' [for God doth know that in what day soever you shall eat thereof, your eyes shall be opened: and you shall be as Gods, knowing good and evil]. 
goes out of his way here to establish this contraposition and to demonstrate the sacrilegious nature of the soothsayers' pretension to know what only God can know as opposed to the pilgrim's revelatory experience, elicited and sanctioned by a gift of divine grace, as clearly articulated by Aquinas:

Si quis ergo hujusmodi futura prænoscere aut prænuntiare quocumque modo præsumpserit, nisi Deo revelante, manifeste usurpat sibi quod Dei est. Et ex hoc aliqui divini dicuntur: unde dicit Isidorus, Divini dicti quasi Deo pleni: divinitate enim se plenos simulant, et astutia quadam fraudulentix hominibus futura conjectant. Divinatio ergo non dicitur si quis prænuntiet ea quae ex necessario eveniunt vel ut in pluribus, quæ humana ratione prænosci possunt. Neque etiam si quis futura alia contingentia, Deo revelante, cognoscat: tunc enim non ipse divinat, idest quod divinum est facit, sed magis quod divinum est suscipit. Tunc autem solum dicitur divinare quando sibi indebito modo usurpat prænuntiationem futurorum eventuum. Hoc autem constat esse peccatum. Unde divinatio semper est peccatum.

[If then anyone claims to foreknow and foretell such like future things by any means whatsoever, except by God's revelation, he is clearly usurping what belongs to God alone. That is why he is called a 'diviner'; Isidore observes that men are called diviners as though they are full of God; they pretend to be charged with divinity and they forecast the future for men by shrewd fraud. Divination then, does not mean plotting the course of events which follows necessity or a statistical majority; these things the mind of man can foreknow. Nor does one divine the future if he learns about its contingent happenings through God's revelation; for he does not divine in the sense that he performs something divine, rather he receives it. Divination occurs when a man usurps to himself, and wrongly, the foretelling of the future. To claim what belongs to God alone is a sin, and in this sense foretelling the future is a $\sin .]^{25}$

This contrast is also articulated in clearly intertextual terms as the representation of the diviners in Inferno $\mathrm{xx}$ deliberately conflicts with the accounts offered by classical sources (most significantly, but not exclusively, Virgil's own Aeneid), heavily manipulating the style, tone, meaning and factual details of its literary antecedents. ${ }^{26}$ While reinforcing the Comedy's

25 Aquinas, Summa Theologiae, IIaIlae, q. 95, a. 1. The Latin text and English translation are taken from St Thomas Aquinas, Summa Theologiae, ed. by Thomas Gilby, 61 vols (Cambridge: Cambridge University Press, 2006), XL, p. 38.

26 But on this aspect of the canto see, for example, Marcello Aurigemma, 'Osservazioni sulla trasformazione dantesca di episodi classici nel canto degli indovini', in Miscellanea di studi danteschi in memoria di Silvio Pasquazi, 2 vols (Naples: Federico Ardia, 1993), I, pp. 3-9. It is important to note, however, that while Virgil is not the only classical source that gets transformed here, Dante's 'correction' to the Aeneid is the only one that is made explicit at 11. 97-99. 
claim to superior authenticity and authority, this discrepancy also reveals the shift in the poem's conception and creative ambitions: to achieve a literary form that is eschatological and prophetic as well as poetic, in which the 'Enea' and 'Paolo' of Inferno, ii. 32 can be embodied, emulated and surpassed. ${ }^{27}$

In this sense, the prominence of the pilgrim's 'pianto' seems to be specifically designed to accentuate this tension, and to call the reader's attention to an element that recasts the protagonist of the journey, and implicitly also his testimony, in an explicitly prophetic light. The emphatic 'Certo io piangea' [surely I wept] (1. 25) in response to the spectacle of the dereliction of human nature caused by the pride of the seers, seems, indeed, to evoke the tears of the prophet Jeremiah when, with characteristic 'emotional extremity', ${ }^{28}$ he is called upon to denounce the false prophets who are deceiving the people of Israel in words that perfectly encapsulate the composite (and more specifically fraudulent) nature of the diviners' sin:

et dixit Dominus ad me Falso prophetæ vaticinantur in nomine meo: non misi eos, et non præcepi eis, neque locutus sum ad eos. Visionem mendacem, et divinationem, et fraudulentiam, et seductionem cordis sui, prophetant vobis. (Jeremiah 14.14)

[And the Lord said to me: The prophets prophesy falsely in my name: I sent them not, neither have I commanded them, nor have I spoken to them: they prophesy unto you a lying vision, and divination and deceit, and the seduction of their own heart.]

The emotive outpouring resulting from this severe condemnation 'deducant oculi mei lacrimam per noctem et diem et non taceant' [Let my

27 I take 'prophetic' here as meaning more than just 'predicting future events'. More broadly, it may communicate a divine message with a profoundly moral and catechising function, which communicates doctrinal teachings and ethic-pedagogical moral objectives that should influence and convince the believers to change their ways. This is already convincingly highlighted in Hawkins, pp. 54-95. See also Lucia Battaglia Ricci, 'Scrittura sacra e "sacrato poema"', in Dante e la Bibbia, ed. by Giovanni Barblan (Florence: Olschki, 1988), pp. 295-321; Giovanni Petrocchi, 'San Paolo e Dante', in Dante e la Bibbia, pp. 235-48. This definition, I believe, reflects better than others the scriptural aspiration and the poetic ambition of the Comedy as both a literary and a scriptural experiment. For a broader discussion on this crucial issue see, more recently, Robert Wilson, Prophecies and Prophecy in Dante's 'Commedia' (Florence: Olschki, 2008), esp. pp. 157-222; Lucia Battaglia Ricci, “'Dice Isaia...". Dante e il profetismo biblico', in La Bibbia di Dante, pp. 49-75; and V. Stanley Benfell, The Biblical Dante (Toronto: University of Toronto Press, 2011), esp. pp. 79-106.

28 Walter Brueggemann, The Theology of the Book of Jeremiah (Cambridge: Cambridge University Press, 2007), p. 33. 
eyes shed down tears night and day, and let them not cease] (Jeremiah 14.17) - is prepared by the flow of tears in the previous chapter:

in abscondito plorabit anima mea a facie superbiae plorans plorabit et deducet oculus meus lacrimam quia captus est grex Domini (Jeremiah 13.17)

[my soul shall weep in secret for your pride: weeping it shall weep, and my eyes shall run down the tears, because the flock of the Lord is carried away captive.]

This is pointedly followed, then, by an incitement to the people of Israel to lift up their eyes and see: 'levate oculos vestros et videte' (Jeremiah 13.20), and reinforced by chapter 23 , entirely dedicated to the denunciation of those who 'speak a vision of their own heart, and not out of the mouth of the Lord' ('visionem cordis sui loquuntur non de ore Domini', Jeremiah 23.16). The narrative prominence assigned to the pilgrim's tears in the specific theological context of this bolgia seems to suggest, therefore, a conscious attempt on Dante's part to evoke the figure of the 'weeping prophet $^{\prime 29}$ and to use the power of his emotive rhetoric to uphold his claim about the prophetic nature of his narrative.

On the fifth terrace of Purgatory (Purg., xix-xxi), crying and weeping are also essential elements of the representation of the penitents correcting their cupiditas and prodigality. In this extended denunciation of the devastating consequence caused by humanity's inability to resist the 'maladetta [...] antica lupa' [accursed ancient she-wolf], Purgatorio xx is central not only in simply structural terms. It presents the strongest condemnation of the vice 'che tutto il mondo occupa' [that fills the whole world] (1. 8), proclaimed emphatically in the canto's opening in Dante's own brief invective, and then reiterated in Hugh Capet's long arraignment. However, since the pilgrim's arrival on the terrace, we know that weeping is one of its defining qualities:

Com'io nel quinto giro fui dischiuso,

Vidi gente per esso che piangea,

Giacendo a terra tutta volta in giuso. (Purg., xix. 70-72)

29 This definition has traditionally been attributed to Jeremiah by the rabbis. See Jack R. Lundbom, Theology in Language, Rhetoric, and Beyond: Essays in Old and New Testament (Cambridge: Clarke, 2014), pp. 99-131. On this and the importance of Jeremiah in Dante's Purgatorio, see Ronald L. Martinez, 'Lament and Lamentations in Purgatorio and the Case of Dante's Statius', Dante Studies 115 (1997), 45-88; and Rachel Jacoff, 'Dante, Geremia e la problematica profetica', in Dante e la Bibbia, pp. 113-23. 
[When I was loosed onto the fifth circle, I saw people weeping there, lying on the earth, all facing downward.]

The sorrow of these penitent souls is, of course, radically different from that of the diviners. A number of prominent elements here seem designed to evoke, nonetheless, the equally tearful infernal procession we witness in Inferno xx. And this is especially the case if we focus on the way in which Dante frames his experience narratively at Purgatorio, xix. 70-72: here again the pilgrim is notably observing - 'io attento a l'ombre' [I walked intent on the shades] (1. 17) - a scene of weeping that in many ways parallels the narrative situation of the canto of the diviners. This orchestrated correspondence is confirmed by significant textual elements such as the 'piangea' (1. 71), a calque of the 'piangea' encountered in Inferno, xx. 25, and the hapax 'drizzate' at 1.78 ('drizzate noi verso li alti saliri' [direct us towards the high ascent]) which immediately reminds us of the poignant 'drizza la testa, drizza e vedi' of Inferno, xx. 31. Sight is, furthermore, the sense initially chosen to verify and relay the experience of the new terrace despite the fact that the prostrate position the souls would naturally hide their faces.

At the opening of Purgatorio xx, resuming the journey after the encounter with Pope Adrian V, the author's voice erupts to curse cupidity, insisting specifically (in his brief invective) on the tears pouring out of these penitent souls:

[...] la gente che fonde a goccia a goccia per gli occhi il mal che tutto'1 mondo occupa (Purg., xx. 7-8)

[the people, melting out through their eyes, drop by drop, the evil that fills the whole world]

The landscape and atmosphere of the terrace are again characterised mainly in terms of the souls' weeping: of their 'pietosamente piangere e lagnarsi' [piteously weeping and lamenting] (1. 18), and their 'chiamar nel pianto' [calling out weeping] (1. 20). Moreover, the pervading sound of the 'pianto' of the terrace suitably frames the central discourse, appearing in rhyming position at 1.20 (pianto/tanto/santo) when Hugh Capet attracts the pilgrim's attention with his lamentation, and then at 1.144 (canto/santo/ pianto) to indicate the conclusion of the episode and the souls' return to their penitential routine. 
Purgatorio $\mathrm{xx}$ centres on Hugh's vehement denunciation of the insatiable and ever-growing cupiditas of his descendants, hyperbolically described with clear biblical undertones as the 'mala pianta / che la terra cristiana tutta aduggia' [the evil plant that overshadows all the Christian lands] (Purg., xx. 43). ${ }^{30}$ His whole speech is heavily imbued with scriptural elements from his opening confession of being the root of a corrupting and degenerating lineage (which directly evokes Paul's well-known first letter to Timothy) $)^{31}$ to his concluding mention of Achan, Sapphira and Heliodorus as examples of cupidity called out by the penitents 'com'el s'annotta' [when night falls] (Purg., xx. 101). ${ }^{32}$ In Hugh's outline of the French ruling dynasty's future, these powerful scriptural echoes are studiously arranged around the increasingly clustering rhythm of the anaphora constructed on the first person of vedere ('veggio' [I see]), repeated six times in 11. 70-93. This creates a compelling contraposition with Virgil's repeated use of 'vedi' and 'mira' in Inferno xx. The openly prophetic tenor of Purgatorio xx confirms the allegorical function of references to sight as the salvific power of revelation in the context of both cantos. The shift from the imperative 'vedi' [see] to the assertive 'veggio' [I see] of Hugh's pronouncements arguably signals, however, a progress from the pilgrim's passive and often apprehensive observation in Inferno to a more active and emphatic participation in the moral journey of Purgatorio.

Alongside the fact that Hugh's speech contains a clearly 'predictive' vision, ${ }^{33}$ framed by characteristically Jeremianic tears and expressed in a precise semantics of sight, a number of other elements contribute to connect this purgatorial canto more distinctively with the prophetic rhetoric of the book of Jeremiah. ${ }^{34}$ In contrast to the deceiving divinations

30 I could not find any previous discussion of the importance of the Book of Jeremiah in the context of this canto, except for one reference to Jeremiah 4.31 for 11. 19-21 in Lund-Mead and Iannucci, p. 257.

31 'Radix enim omnium malorum est cupiditas' [greed is the root of all evil] (i Timothy 6.10). For this verse, Lund-Mead and Iannucci refer instead to i Maccabees 1.11: 'et exit ex eis radix peccatrix $[\ldots]$ '. See Lund-Mead and Iannucci, p. 258. But in this context it is also interesting to contrast Hugh's expression 'mala pianta' with Jeremiah 23.5 where David is described as 'germen iustum'.

32 Respectively in Joshua 6.17-19, Acts 5.1-11 and ii Maccabees 3.1-40.

33 Wilson, p. 85.

34 These would include also the extensive use of repetitions and of rhetorical questions that also characterises Jeremianic rhetoric. As the Comedy intertwines universality and historicity, allegory and biography, poeticism and realism, in a similar way to Jeremiah, it would be worth investigating in more depth Dante's significant use of the Book of Jeremiah in his poem and in his other works. 
of faithless impostors, the scriptural reliability and moral righteousness of Hugh's truthfully prophetic discourse (and of Dante's through his voice) are reinforced by his denunciation of his descendants' systematic 'rapina' [plundering] that plagues all the lands they cross 'con forza e con menzogna' [with force and fraud] (11. 64-65). This condemnation of betrayed justice, repudiated blood ties and indignation at 11. 70-93 closely recalls Jeremiah's critique of corrupt rulers (Jeremiah 22.13-19 and 23.1-2 but also 5.27-28) displaying an equally forceful 'rhetoric of judgment'. ${ }^{35}$ And, as repeatedly in Jeremiah, this accusatory speech also culminates in a fervent appeal to the Lord's rightful vengeance at 11. 94-96:

O Segnor mio, quando sarò io lieto a veder la vendetta che, nascosa, fa dolce l'ira tua nel tuo secreto? (Purg., xx. 94-96)

[O my Lord, when will I be gladdened seeing the vengeance, now hidden, that makes your anger sweet in your secret counsel?] $]^{36}$

The alliterative emphasis on witnessing the Lord's 'vendetta' forcefully links these verses also to the 'Laetabitur justus cum viderit vindictam; manus suas lavabit in sanguine peccatoris' [he just shall rejoice when he shall see the revenge: he shall wash his hands in the blood of the sinner] (Psalms 57.11). While signalling the conclusion of Hugh's angry tirade and a change of tone and narrative direction, this emphatic question alludes back to Dante's own anger and fervent plea that conclude his brief invective at 11. 10-15 ('quando verrà per cui questa disceda?' [when will he come who will drive her away]), ${ }^{37}$ anchoring both to a renowned locus in a Pauline

35 See, for example, Brueggemann, pp. 35-41 and pp. 75-81 (p. 77). For the distinctive features of Jeremiah's rhetoric, see also J. L. Berquist, 'Prophetic Legitimation in Jeremiah', Vetus Testamentum 39.2 (1989), 129-39; L. Boadt, 'The Poetry of Prophetic Persuasion', The Catholic Biblical Quarterly 59 (1997), 1-21.

36 See for instance 'Tu autem Domine Sabaoth qui iudicas iuste et probas renes et cor videam ultionem tuam ex eis [O Lord of Sabaoth, who judgest justly, and triest the reins and hearts, let me see thy revenge on them] (Jeremiah 11.20), or similarly 'et tu Domine exercituum probator iusti qui vides renes et cor videam quaeso ultionem tuam ex eis' [And thou, O Lord of hosts, prover of the just, who seest the reins and the heart: let me see, I beseech thee, thy vengeance on them] (Jeremiah 20.12); and the more dramatic Jeremiah 10.25. For the importance of the theme of vengeance in Jeremiah, see, in particular, $M$. Avioz, 'The Call for Revenge in Jeremiah's Complaints (Jer. XI-XX)', Vetus Testamentum 55.4 (2005), 429-38.

37 As some commentators have noted, this is strategically wedged at the beginning of the canto between his encounter with a pope and a king, ie. the 'due soli'. 
epistle: 'date locum irae scriptum est enim mihi vindictam ego retribuam dicit Dominus' [avenge not yourselves, but rather give place unto wrath: for it is written, Vengeance is mine; I will repay, saith the Lord] (Romans 12.19). The same anguished appeal returns in Dante's sonnet of exile, Se vedi li occhi miei di pianger vaghi, in which we encounter a similar plea to the Lord to punish the iniquity of a 'gran tirranno' [great tyrant] whose poison 'ha già sparto e vuol che'l mondo allaghi' [has already poured forth in the wish that it may flood the world]. This is closely reminiscent of the pervasive proliferation of the 'mal che tutto ' 1 mondo occupa' (Purg., xx. 8)..$^{38}$ In the sonnet as well as in Purgatorio xx, a fitting punishment is demanded for the new Pilate ('nuovo Pilato si crudele', 1. 91), avid usurper ('sanza decreto', 1. 92) and destroyer of justice.

Justice is, of course, the central theme of Paradiso xvii-xx in which the viator encounters the just souls in the Heaven of Jupiter, an experience significantly inaugurated by the powerful visual re-enunciation of the imperative and admonishing opening of the Book of Wisdom: 'Diligite iustitiam qui iudicatis terram' [Love Justice you who judge the earth] (Par., xviii. 91-93). This spectacular display, with its perceptional intensity and its scriptural solemnity, fittingly prepares the experience of Paradiso $\mathrm{xx}$, a canto 'of intense and compact mysticism' where this scriptural frame of reference is consciously heightened. ${ }^{39}$ The focus on the eagle's eye in itself and specifically on David, the archetypical just king, as its 'pupilla' [pupil], certainly occasions this canto's dense intertextuality with the Psalms, particularly Psalm $16 .^{40}$ The characteristic rhythm of the Psalms is also evoked by the patterned cadence of the eagle's description of the souls that form the rest of its eye, whose specific beatification is individually introduced with the regular anaphoric repetition of the same formula

38 This uniquely political sonnet rehearses many of the motives of Purgatorio xx, again interestingly and forcefully linking the 'vista' and the 'pianto', and displaying a significant numbers of scriptural references. It also presents a rare rhyme in 'ugge' in the quatrain, highly reminiscent of the 'uggia' of aduggia/Bruggia/giuggia of 11. 44, 46, 48. For a detailed commentary of the sonnet see Dante Alighieri, Rime, ed. by Domenico De Robertis (Florence: Edizioni del Galluzzo, 2005), pp. 246-48, and Dante Alighieri, Opere. Rime, Vita Nova, De vulgari eloquentia, ed. by Claudio Giunta, Guglielmo Gorni and Mirko Tavoni (Milan: Mondadori, 2011), pp. 540-51 where, however, Purgatorio xx is mentioned only very briefly.

39 See Serianni, p. 3.

40 See Psalms 16.7-8: 'mirifica misericordias tuas qui salvos facis sperantes in te a resistentibus dexterae tuae custodi me ut pupillam oculi sub umbra alarum tuarum proteges me'. 
'ora conosce' [now he knows]. ${ }^{41}$ This further underlines the scriptural significance of sight and of references to the eyes as privileged metaphors for revelation, as explicitly used later on in the canto at 11. 118-26. But it is also indicative of the prophetic mode the text is trying to emulate, which notably characterises also the first part of the eagle's speech in canto xix. ${ }^{42}$

The long speech on justice and salvation pronounced by the eagle in Paradiso xix already frames references to the inscrutable nature of divine judgement in terms of seeing, in the double anaphora of 'Lí si vedrà' (ll. $115,118,121)$ and 'Vedrassi' (11. 124, 127, 130). ${ }^{43}$ Then, in canto $x x$, this insistence on sight and eyes continues as 'lo benedetto segno' [the blessed sign] (1. 86) asks the pilgrim to 'riguardar fisamente' [gaze fixedly upon] (1. 33) its eye, indicated with a periphrasis on the visual faculties of 'aguglie mortali' [mortal eagles] (1. 32) centred on the dittology 'vede e pate' [sees and endures] (1. 31). ${ }^{44}$ David is surrounded by five other just souls who form the brow of the eagle's eye, each designated with reference to both his earthly and his heavenly circumstances except for the last one, Ripheus. ${ }^{45}$ In his case, in the first terzina, the eagle completely neglects any reference to Ripheus's fleshly existence, instead boldly and rhetorically asking:

41 This is repeated six times, once for each of the just souls mentioned, every time opening the first verse of the second terzina of the block of two dedicated to each soul.

42 The eagle's invective in canto xix is specifically connected to Jeremiah in a number of ways: in its generalisation of the condemnation of all evil nations (Jeremiah 25:13); in it accusation of those who try to hide their iniquity professing Christ's name (Jeremiah 7:11); and in its call for divine justice (Jeremiah 22).

43 Many commentators have remarked on the close connection of Paradiso xix and xx not only because of the continuity in both cantos of the eagle's discourse, but also because of a calculated chiasmic correspondence in the cantos' distribution of doctrinal matter: in Paradiso xix an abstract theological discussion is followed by a historical excursus, while in Paradiso xx the historical contextualisation of the souls mentioned is followed by the discussion of predestination. The symmetric use of anaphoras in the two cantos is part of the same pattern.

44 There is no need to reiterate here the importance of vision, more generally, in the ascending narrative of Paradiso that openly links the pilgrim's ability to see to his capacity to understand the mysteries of revelation and, as such, to become ready for the ultimate vision at the end of his journey.

45 The case of the Emperor Trajan is just as scandalous as that of the Trojan Ripheus. However, in my view, it is extremely significant that the text specifically highlights the exceptionality of the latter while framing the former in the same formula used for the other just rulers. We should not ignore this by assimilating the case of Trajan and Ripheus. The issue of the salvation of 'virtuous pagans' in general is, of course, an immensely complex issue. See, most recently, John Marenbon, 'Pagans and Philosophers: The Problem of Paganism from Augustine to Leibniz (Princeton, NJ: Princeton University Press, 2015), pp. 188-213. 
'Chi crederebbe giù nel mondo errante che Rifëo Troiano in questo tondo fosse la quinta de le luci sante?' (Par., xx. 67-69)

[Who would believe, down in the erring world, that Ripheus the Trojan would be the fifth of the holy lights in this round?]

Critics have fittingly called the presence of the pagan Ripheus here a scandal and an enigma, as the only functional source for his inclusion in the Heaven of Jupiter appears to be Virgil's Aeneid (ii. 426-28). His presence is admittedly so idiosyncratic that the pilgrim's (and the reader's) declared inability to understand is reasserted twice: first, in his direct and impetuous questioning 'Che cose son queste?' [What things are these?] (1. 82); and then when the eagle embarks on discussing in detail Ripheus's and Trajan's salvation:

'Io veggio che tu credi queste cose perch'io le dico, ma non vedi come; sí che, se son credute, sono ascose'. (Par., xx. 88-90)

[I see that you believe these things because I say them, but do not know how, so that, though they are believed, they are hidden.]

This elucidation occupies a significant section of the canto (11. 79-129). Whilst emphasising the allegorical association of sight with the acquisition of salvific revelation, it also introduces a further theological discourse on the relationship between prophetic vision and spiritual receptivity, between human understanding and faith, as we might expect at this stage in the pilgrim's journey. ${ }^{46}$ This terzina, in fact, introduces a fundamental distinction between the eagle's assertive 'Io veggio' [I see] and the pilgrim's inability to see: 'tu... non vedi' [you do not see], marking the boundaries of human understanding that its speech will clarify. On the one hand, Ripheus's salvation is presented precisely in the biblical and, more specifically, prophetic terms that associate human 'vedere' [seeing] with

46 Barberi Squarotti, pp. 252-57. In this sense, it is also interesting to highlight the composite nature of the pilgrim's sensorial experience in the Heaven of Jupiter, where the sounds and silences are synchronised with the visual inputs, albeit with no possibility of being communicated in human terms. This reflects a recurring aspect of prophetic language where videre and audire are counterparts of the same spiritual and intellectual process of illumination. 
faith in revelation: 'Dio li aperse / 1'occhio a la nostra redenzion futura' [God opened his eyes to our future redemption] (Par., xx. 122-23). This explicitly scriptural frame of reference is established at 11. 94-96, where Dante incorporates into the eagle's explanation half a verse, part vernacularised, from Matthew's gospel: ${ }^{47}$

'Regnum celorum violenza pate

da caldo amore e da viva speranza, che vince la divina volontate.' (Par., xx. 94-95)

[Regnum celorum suffers the violence of burning love and lively hope that overcome God's will.]

On the other hand, this demarcation offers an opportunity to clarify the absolute inaccessibility of the mysteries of divine justice and predestination, which are even beyond the grasp of the souls already saved and rejoicing in the beatific vision of God. The doctrinally dense lectio, imbued with technical terms, strident Latinisms and further scriptural elements, ${ }^{48}$ concludes with a significant monitum to all 'mortali' [mortals] to embrace revelation and to accept with the necessary humilitas the inescapable limits of our understanding, ${ }^{49}$ clarifying whilst also asserting the limits of the poet's own 'corta vista' [short sight] (1. 140).

On the basis of its assumed divine origin, Dante's text defiantly sanctions, in this way, its own superior authority and scriptural status. But whether or not we choose to accept this claim, it is undeniable that the revealed nature of the Comedy is here clamorously trusted to the exemplum ${ }^{50}$ of a purely literary character whose complete eccentricity in Paradiso could not be missed, 'unum infidelem paganum Ripheum'.${ }^{51}$ As such, it is defined emphatically in terms of its relation to its poetic status and to Virgil's text. ${ }^{52}$

47 'regnum caelorum vim patitur et violenti rapiunt illud [the kingdom of heaven suffereth violence, and the violent bear it away] (Matthew 11.12).

48 See, for instance, 'quiditate' (1. 92) and 'passuri' (1.105).

49 This motif is anticipated a number of times in the poem, most significantly in Par., xix. 79-81 when the eagle mocks human aspirations to fathom divine justice with a 'veduta corta d'una spanna' [with sight as short as a handbreadth].

50 See Villa, 'I cieli di Marte e Giove', pp. 197-98.

51 Benvenuto, Comentum, V, p. 263.

52 This is, in fact, much more than just a 'touching tribute'. See Ernst Robert Curtius, European Literature and the Latin Middle Ages, trans. by Willard R. Trask (Princeton, NJ: Princeton University Press, 1953), p. 359. But see also the convincing case put forward by Scott (p. 190) for the determinant influence of Boethius in contributing to the choice of Ripheus in this particular instance. 
Dramatically reversing the fate of this 'iustissimus unus' might certainly appear as yet another conspicuous correction of the Aeneid. ${ }^{53}$ However, in a 'vertical' perspective, it is possible to trace a much more complex and directed 'dialettica dell'intertestualità' [intertextual dialectic] $]^{54}$ that, at least in part, can contribute to illuminate further the presence of such a significantly Virgilian reference at this stage in the pilgrim's journey ${ }^{55}$

Inferno $\mathrm{xx}$ presents, in fact, not only another one of these corrections in its retelling of the myth of the foundation of Mantua but also a rather articulate intertextual and metatextual discourse, particularly in its unusual opening which addresses the reader with a startling admission:

\author{
Di nova pena mi conven far versi \\ e dar matera al ventesimo canto \\ de la prima canzon, ch'è d'i sommersi. (Inf., xx. 1-3)
}

[Of a strange new punishment I must make verses and take matter for the twentieth song in this first canticle, which is of those submerged.]

The technical language here, as well as throughout the canto and into the subsequent one, has encouraged critics to reflect on its statements mainly in terms of style. ${ }^{56}$ But it is actually a powerful signal that Dante is developing in this canto a specific self-reflective discourse. This is clearly the case in relation to the poem's composition. In an absolutely unique instance, Inferno xx explicitly mentions the canto's number 'ventesimo' (l. 2 ), naturally projecting the readers' mind towards the other Twenties. At the same time, the word 'canto' in rhyming position (with its suggestive Virgilian resonance) also sets up a further, and compelling 'vertical' connection: 'canto' rhymes with 'quanto' and 'pianto' in Inferno, xx. 2, 4, 6, with 'santo' and 'pianto' in Purgatorio, xx. 140, 142, 146, and with 'santo' and the rare 'altrettanto' in Paradiso, xx. 38, 40, 42.

53 For a detailed analysis of this dynamic, see especially Robert Hollander, Il Virgilio Dantesco. Tragedia nella 'Commedia' (Florence: Olschki, 1983).

54 Scott, p. 192.

55 As already noted by Benvenuto in his commentary: 'Verumtamen autor elegit potius istum nominatim quam alium, quia Virgilius fecerat singularem commendationem de justitia eius, ut jam patuit ex dictis'. See Comentum, V, p. 263.

56 Especially concerning the references to 'canto' and 'canzone' but also more significantly for the definition, discussed below, of Virgil's Aeneid as 'tragedía' at 1. 113 in relation to the consciously 'comedic' style, characterising the whole canto, which Parodi defined 'quasi poemetto popolare'. 
Even more interestingly, from our point of view, Dante underlines the canto's relationship with classical literature. Each of the ancient diviners mentioned in Inferno $\mathrm{xx}$ is connected to a crucially important literary antecedent for the Comedy: Amphiaraus from Statius's Thebaid, Tiresias from Ovid's Metamorphoses, Aruns from Lucan's Pharsalia, and Manto from Virgil's Aeneid. The close proximity of these auctores, with the immensely significant exception of Statius, naturally brings to mind the 'bella scola' of Inferno iv, implicitly reminding us of their spiritual error and consequent damnation. This is particularly apparent in the long digression on the origins of the city of Mantua occasioned by the mention of Manto, 'an intertextual node of particular bumpiness in the Comedy's never smooth texture'. ${ }^{57}$

'Però t'assenno che, se tu mai odi originar la mia terra altrimenti, la verità nulla menzogna frodi'. (Inf., xx. 97-99)

[Therefore I advise you, if you ever hear any other origin given for my city, that you let no lie defraud the truth.]

Of course, the lie referred to here is the one put forward in Virgil's Aeneid, which is constructed as the 'menzogna' in direct opposition to the 'verità' of the Dante's Comedy. ${ }^{58}$

This contraposition would seem to be confirmed by the designation of Virgil's poem as 'tragedìa' (1. 113) as opposed to Dante's 'comedìa', mentioned for the first time in Inferno, xvi. 128, where his vision is significantly described as 'quel ver c'ha faccia di menzogna' [that truth which has the face of falsehood] (1. 124). But there is nothing so simple in Dante's relationship with his 'maestro e [...] autore' [master and [...] author] (Inf., i. 85), the 'dolcissimo patre' [most sweet father] (Purg., xx. 97-99) Virgil, within or outside the text's narrative. In fact, although in the Inferno we can perhaps trace a pattern of progressive displacement,

57 Barolini, 'Canto XX', p. 275.

58 Or so we are told almost unanimously in all commentaries. In fact Manto's portrait in Inferno $\mathrm{xx}$ as 'vergine cruda' appears constructed not only to directly resemble Lucan's 'effera' and 'dira' Erichthon in the Pharsalia (vi. 508; 564), also called 'cruda' in Inf., ix. 23, but also Statius's own description of Manto as a 'innuba' priestess (Theb. iv. 463 and vii. 758), against the Virginian suggestion that she was Ocno's mother (Aen., x. 198-200). See Padoan's entry on Manto in ED, III, pp. 810-11. This aspect is also indicated in Hollander, 'The Tragedy of Divination', pp. 188-95; and Gentili, p. 674. 
the developing representation of Virgil and the continued reference to his Aeneid in Purgatory and Paradise would seem to suggest a rather different trajectory, one that develops an increasingly complex but self-conscious celebration of the inestimable poetic value of Virgil's work, despite his limitations..$^{59}$ If, indeed, Dante asserts the validity and superiority of his vision, and of course implicitly also of his poetry, consciously adopting a prophetic style and an openly scriptural framework, he does not deny the poetic auctoritas of Virgil as well as of the other classical poets celebrated in and through the poetry of the Comedy. On the contrary, the exemplary value of Virgil's poetry, despite the defeats and limitations of his characterization in Dante's poem, continues to inform his poetic discourse and to offer (with the other classics) a fundamental expressive and cultural model.

The novitas and superiority of Dante's own poetry are constantly measured, therefore, against the literary tradition that his poem tries at the same time to celebrate and to challenge, as famously in Paradiso xxv:

con altra voce omai, con altro vello ritornerò poeta, (Par., xxv. 7-8)

[with other voice by then, with other fleece I shall return as poet]

Explicitly and emphatically claiming the title of 'poeta', in this sense, has a double function, particularly in the context of Paradiso: whilst allowing Dante to maintain the necessary humility demanded by prophetic discourse ${ }^{60}$ highlighting the humanity of his language and accepting its inherent limitations, ${ }^{61}$ it also enables him to claim an evident superiority over all other poets precisely because of his poetry's exclusive scripturality. The poetic and the scriptural level are therefore inextricably intertwined,

59 Statius calls the Aeneid 'divina fiamma / onde sono allumati più di mille' [divine flame that has kindled more than a thousand], 'mamma' [mother] and 'nutrice' [nurse] in Purg., xxi. 95-98; and, in Purg., xxii, we find also the only occurrence of the noun 'cantor' outside Paradiso to refer to a non-blessed soul, where it qualifies Virgil as the 'cantor de bucolici carmi', with an interesting correspondence to David's designation in Paradiso xx as 'il cantor de lo Sprirto Santo' (1. 38).

60 For the paradoxical coexistence, particularly in the Paradiso, of Dante's declared poetic ambition and desire to affirm both his novitas and superiority, and his awareness and strong affirmation of the necessity of humility in human discussions of divinity, see especially Robin Kirkpatrick, Dante's 'Paradiso' and the Limitations of Modern Criticism (Cambridge: Cambridge University Press, 1978), pp. 28-50.

61 Valerio Lucchesi, 'Giustizia divina e linguaggio umano. Metafore e polisemie del contrapasso dantesco', Studi Danteschi 63 (1991), 53-126. 
reciprocally validating, and equally functional in the creation of a uniquely sacred poem that offers a renewed belief in the power of poetry to inspire others on the path to salvation. In this sense, what emerges consistently in the Twenties is the way in which the clear scriptural framework is used to underpin and legitimise a poetic discourse with bold cultural and moral ambitions. In fact, although the opportunity to experience the other world is explicitly identified as a free gift of divine grace and entirely dependent on divine authority, the poetic language that express Dante's eschatological vision are resolutely and provocatively professed as his own. 